\title{
Do not resuscitate orders - managing the dilemma
}

Douglas B. Craig MD FRCPC,
George C. Webster DMIN
$\mathrm{T}$

HE presence of a "do not resuscitate" (DNR) order for a patient scheduled for surgery may create a dilemma for the anaesthetist and others responsible for the patient's care. Should the DNR order be suspended, in whole or in part? Should it be maintained, either as written or in a modified version? Does the maintenance of the DNR order, or its suspension, lead to a situation where the anaesthetist feels morally compromised? This review will examine the basis for the various elements of this dilemma and its resolution. Although our review is specifically focused on DNR orders in the operating room, similar uncertainties also arise with respect to the status of preexisting DNR orders in other acute care settings, for example intensive care units (ICUs).

In our view "respect for persons" is the underlying principle that ought to guide, inform and shape decision making. We will discuss this further when we outline our approach to DNR orders.

The general issue of DNR orders has been in evolution since the early 1970's when the results of the widespread and indiscriminate application of resuscitation procedures began to be questioned. ${ }^{1,2}$ The specific issue of DNR orders in patients undergoing surgery has been the subject of more recent analysis. ${ }^{3-13}$ Some earlier articles questioned the compatibility of surgical procedures and DNR orders, leading to the suggestion that DNR orders be automatically suspended during surgery or, more specifically, for the entire peri-operative period. More recent analyses have confirmed the appropriateness of some surgical interventions in patients with DNR orders. In these circumstances it has been important to find appropriate ways to accommodate the pre-existing DNR order. At the same time, the inappropriateness of simply accepting DNR orders as written and without discussion is emphasised, leading to the suggestion that DNR orders should be reviewed and modified, if warranted, when patients undergo surgery.
A further element in the discussion has been the recognition of the personal and professional ethical concerns of the anaesthetist or other health care workers participating in the care of patients with DNR or other orders restricting treatment. ${ }^{3,10,14} \mathrm{We}$ will conclude our review with commentary on this issue.

Because of the importance and the complexity of the many interdependent elements of the DNR issue we find it helpful to review directly some of the basic elements of the issue, as opposed to simply referring the reader to earlier analyses. After completing this analysis we will suggest approaches that should help caregivers work through those situations where patients with a preexisting DNR order may need surgery and anaesthesia.

We conclude our introductory comments by noting that although the specific legal aspects of the DNR issue vary between countries, or even within countries, the general principles of this analysis, based on the situation in Canada, are likely also to apply elsewhere.

\section{The origin of DNR orders}

Do not resuscitate orders normally originate in one of two ways. A DNR order may be proposed by caregivers or a request not to be resuscitated may originate with a patient or a patient's family. In the first instance a particular "treatment," specifically cardiopulmonary resuscitation (CPR), may not be "medically indicated" for a specific patient. This would include, for example, a patient with known widespread metastatic cancer which has failed to respond to treatment and who is likely to die from the underlying disease in the near future.

The need for an order confirming that resuscitation is not indicated arose from the near universal application of CPR in cardiac and/or respiratory arrest, beginning in the early 1960s. The uncertainty surrounding this issue led in Canada, at the end of a long and complex process, to the publication of the Joint Statement on Resuscitative Interventions. ${ }^{15}$ The Statement was prepared by the Canadian Healthcare Association, the Canadian Medical Association, the Canadian Nurses

From the *Department of Anesthesia, University of Manitoba, LB315, Health Sciences Centre, Winnipeg, Manitoba, R3E 1X2 Canada. E-mail: dcraig@hsc.mb.ca

tHealth Care Ethics Service, St. Boniface General Hospital, Winnipeg, Manitoba, R2H 2A6 Canada. E-mail: gwebster@sbrc.umanitoba.ca 
Association and the Catholic Health Association of Canada. The Statement provides a concise analysis of the basic resuscitation issue and attempts to define when resuscitative interventions are appropriate and when they are not. While the Statement notes "there is no obligation to offer a person futile or nonbeneficial treatment," it also recognises the complexity of these concepts and leaves to individual health care institutions the task of defining "futility" and "nonbeneficial." Nevertheless, the Statement does provide a firm foundation for the consideration of DNR orders, in those circumstances outlined in the Joint Statement. It is also made clear that the presence of a DNR order does not imply the withholding or withdrawal of other forms of treatment or care, including surgery, palliative care or other treatment interventions. The key elements of the Statement relating to the guiding principles for CPR policies, indications for resuscitation, and for DNR orders in the absence of these indications, are summarised in Tables I, II and III.

A DNR order (or its equivalent) may follow a declaration by the patient, or someone authorised to act on the patient's behalf, placing limits on future interventions. A decision on the part of a patient to accept a proposed course of investigation or therapy ought to be an "informed decision." Informed consent is a fundamental legal and ethical requirement in the caregiver patient relationship. It is now widely accepted that patients with decision-making capacity may accept treatment or refuse a recommended investigation or treatment, even if the refusal might lead to what, in the caregiver's view, is a less than desired outcome, even death. For some, the "right of refusal" is absolute and, unlike the doctrine of informed consent, refusal is not limited by any legal requirement concerning provision of information to those persons refusing treatment. Notwithstanding this, the fundamental premise of care for persons dictates that, even in the absence of a legal requirement, there is a moral obligation for the caregiver to attempt to ensure that decisions to refuse treatment are informed.

In addition to a direct declaration by a competent person declining future resuscitation attempts, advance directives (i.e., instructional and/or proxy directive) properly executed are an alternate means for an individual to express a decision to forego CPR.

The recognition that a DNR order (or equivalent) originating with a patient or substitute decision-maker may have been made without complete and correct information, particularly about the specifics of anaesthetic and other perioperative care, is of critical importance. It is also important to recognise that a request for a DNR order may have been written or communicated to a substitute decision maker at an earlier more
TABLE I Guiding principles for CPR policies

- Open communication/discussion/sensitivity.

- Sufficient information given about benefits/risks/likely outcomes.

- Patients' right to refuse or withdraw consent.

- Equal rights for patients unable to make own decisions.

- No obligation to offer futile/non-beneficial treatment.

\section{TABLE II CPR outcomes}

\section{Benefit likely}

- There is a good chance that CPR will restore cardiac and respiratory function and that the restored function will be maintained. The likelihood of the person's returning to his or her pre-arrest condition is high.

\section{Benefit uncertain}

- The person's condition or prognosis or both may not have been assessed before the loss of cardiac and respiratory function. It is unknown or uncertain whether CPR will restore functioning. The subsequent prognosis or the likelihood of adverse consequence is also unknown or uncertain.

Benefit unlikely

- There is little chance that CPR will restore cardiac and respiratory function; even if the function is restored, it is unlikely to be maintained. The likelihood of the patient returning to his or her pre-arrest condition is low.

Benefit absent

- There is almost certainly no chance that the person will benefit from CPR, either because the underlying illness or disease makes recovery from arrest virtually unprecedented or because the person will be permanently unable to experience any benefit.

TABLE III Situations in which CPR should/should not be performed

Should

- People likely to benefit from CPR should be given this treatment if the need arises, unless they have specifically rejected it.

- People for whom the benefit of CPR is uncertain or unlikely should be given this treatment if the need arises, unless they have specifically rejected it. CPR should be initiated until the person's condition has been assessed.

\section{Should not}

- People who have rejected CPR and those who almost certainly will not benefit from it should not be given this treatment if an arrest occurs.

remote time, so that the specific current circumstances of the patient might not have been anticipated when the advance directive was completed.

\section{Iatrogenic events}

The issue of the status of iatrogenic events (broadly defined as adverse occurrences resulting from diagnostic or therapeutic interventions) has been identified as one of the most confounding elements in the DNR/OR discussion. This issue was discussed in some earlier analyses, but it has only recently been specifical- 
ly examined in detail. ${ }^{16}$ Casarett and Ross discuss iatrogenic complications as possible valid modifiers of DNR orders but reject the premise that the origin of the complication justifies overriding the DNR order. Their rejection arises from an analysis of the balance between the principle of nonmaleficence (do no harm) and the principle of respect for patient autonomy. They suggest that, understood as a balance, the principle of nonmaleficence establishes only a partial or apparent duty to avoid harm and that this should not outweigh respect for the patient's autonomy, as expressed in the advance directive. They also reject the notion that resuscitation after iatrogenic cardiac arrest, despite a valid DNR order, is automatically justified because it is likely to be successful.

At the same time they note that there will be instances where an advance directive (in whatever format) should be overridden. This is because of questions about the intent of the advance declaration, noting that often it is intended as a general declaration, and it may have several potential meanings. Ideally, these critical distinctions should be resolved in advance, either at the time of writing of the DNR order or later, in relation to the specific circumstances of the patient. The possibility of iatrogenic complications, and their status, can and should be addressed with the capable patient or appropriate substitute decision maker. It is important to note, in relation to the status of DNR orders in the operating room, that Casarett and Ross do not include in their analysis specific issues related to anaesthetic or other perioperative care.

Management of DNR orders in the operating room Since the publication of the initial articles dealing with the status of DNR orders in the operating room there has been an evolution in the proposed approach to the management of DNR orders in patients undergoing surgery. Earlier proposals addressing the issue tended to focus on two options: automatic continuation or automatic suspension of DNR orders for the entire perioperative period. These have been replaced by more complex considerations, outlined below.

Some proponents of automatic suspension suggest there is an absolute incompatibility between a DNR order and a surgical procedure. There is also an obvious and attractive (for some) expediency associated with the suspension approach, in that the required surgical intervention is completed without any need for the basic issues involved to be understood or even addressed.

It is important to note in this context that the automatic (i.e., without discussion with the patient or the patient's proxy) enforcement of DNR orders for patients undergoing surgery is equally problematic.

An important theme in the developing literature on DNR orders in the operating room has been the admonition that those providing care to the patient understand, as clearly and as fully as possible, the context of the specific DNR order. When and why was the order instituted? Have the circumstances changed? Was the decision to establish the DNR order an informed decision? Is the order clear and specific or open to interpretation?

Another very important issue is the distinction between the meaning of "resuscitation" as understood by patients, and many health care workers, and the view of the same term by anaesthetic practitioners. The fact that intravenous administration of fluids, muscle relaxants and vasoactive drugs, tracheal intubation and mechanical ventilation, and other "invasive" procedures are routine parts of modern anaesthesia is likely fully appreciated fully only by anaesthetic practitioners themselves. It is critical therefore that the details of such routine management activities be discussed not only with the patient but also others involved in the patient's care. In this situation the quality of communication and not simply the quantity of information shared between the anaesthetist and patient, is of critical importance. This "communication" goes to the very heart of the therapeutic relationship. If it is the patient's intent to withhold consent via the DNR order for treatment of cardiopulmonary arrest only, while at the same time accepting other elements of "resuscitation," this must be addressed in advance, whenever possible.

\section{Required reconsideration}

In 1993 the American Society of Anesthesiologists (ASA) was the first organisation to publish a Guideline dealing with DNR orders, or other equivalent directives limiting treatment. ${ }^{17}$ One year later the American College of Surgeons (ACS) published a Statement addressing the same issue. ${ }^{18}$ Both the ASA Guideline and the ACS Statement reject the automatic suspension approach. The ASA Guideline notes that automatic suspension policies "may not sufficiently address a patient's rights to selfdetermination in a responsible and ethical manner." The ACS Statement conforms, but also adds that a policy to automatically maintain and enforce all DNR orders is also inappropriate and may lead to inappropriate perioperative and anaesthetic management. The Statement concludes with a recommendation that there be a policy for "required reconsideration" of previous advance directives before surgery, an approach first proposed in 1992 by Cohen and Cohen. ${ }^{19}$

At the time of preparation of this summary (December 1997) the authors were unaware of any national guidelines in Canada (published or in prepa- 
ration) similar to those published by the ASA or ACS. This is a significant deficiency which must be addressed. Despite the lack of national guidelines some hospitals have included in their policies for appropriate use of CPR clauses requiring DNR orders to be reviewed in specified circumstances, for example related to surgical care or transfer to an ICU. ${ }^{20}$

The "required reconsideration" approach proposed by Cohen and Cohen ${ }^{19}$ was for a mandated reconsideration of DNR orders based either on the length of time a DNR order had been in effect or on the treatment setting. They suggest that the movement of a patient from one setting (e.g., a nursing home) where survival from cardiac arrest is unlikely, to another setting (e.g., an acute care hospital) where specific timelimited therapies increase the risk of a cardiac arrest, but where immediately available resuscitation makes a positive outcome more likely, warrants reconsideration of the specifics of the DNR order.

\section{A modest proposal}

Except in clinical situations where a delay is not possible, it is our view that the stanus of the DNR order must be reviewed - the required reconsideration approach discussed above. A valuable first step in this reconsideration process relates to the details of the DNR order itself, unrelated to the proposed surgical procedure. The full context of the DNR order must be understood by both patients and caregivers. There should be no assumptions. Are the reasons for the existing DNR order still relevant? Is the DNR order clear and unambiguous, both for the patient (or the patient's substitute decision maker) and for the physicians and other health care workers caring for the patient? Unrelated to the pending surgery are changes to the existing DNR order warranted?

It is often assumed that everyone party to a discussion about a DNR order understands the intent and the importance of the order. Some DNR orders, particularly those communicated via a written advance directive can be very difficult to interpret. It is often not clear how much the individual understood when they completed the advance directive and caregivers often have great difficulty "translating" the written instruction to the matter or context at hand. Knowing whether patients who are now incapable actually understood what they were "agreeing to" when they completed an advance directive can create major uncertainty for caregivers and, on occasion, for substitute decision makers.

Our first suggestion, then, is the creation of as clear and understandable (for all parties) a starting point as is possible about the specific details of the DNR order, allowing the subsequent steps focussed on DNR order status during surgery to proceed on their own merit.

We note a key feature of both the ASA and the ACS guidelines, and an important message in many recent articles, is the recognition that there is no single or correct "solution" for all situations. In caring for different patients, in what appears to be the same clinical situation, it may be appropriate and acceptable to retain the DNR order unchanged for the perioperative period, or to retain it in a modified structure, or to suspend it. For the same patient in different clinical situations similar options will likely apply. The approach to the DNR order status, then, must be individualised and tailored in such a way that it meets the needs of, and, to the greatest extent possible, respects the values of the individual patient.

A frank and open dialogue with the patient (or substitute decision maker) is essential. This conversation ought to include not only the provision of information and response to questions, but it should be characterised by what several authors have described as a process of "negotiation." Waisel and Truog suggest that this process have as its end goal a "negotiated and universal agreement" with the patient as one party to the agreement and the members of the care giving team the second party. ${ }^{13}$

The ASA Guideline suggests a primarily procedurebased approach to this discussion/negotiation, listing specific care elements (e.g., cardiac massage, postoperative ventilatory support, vasoactive drug administration) which should be addressed, in each patient care situation. It must be recognised however that this approach will not be appropriate or even possible for all patients and all situations.

A second possible approach is goal-based rather than procedure based, and is focused on ascertaining and clarifying the patient's views and preferences with respect to outcome. Dickens has noted the importance of distinguishing between "means" of treatment and "goals" of treatment. ${ }^{21}$ In the context of consent and the therapeutic relationship Dickens observed that physicians and other care givers bring information to patients about diagnosis, prognosis and means available to treat a particular condition or malady. Patients, for their part, bring a certain "history" to the therapeutic relationship that is informed and shaped by personal values and beliefs. Physicians and other care givers must converse with patients in a meaningful way to learn more about the patient's values and belief system. In this way, they will come to know more clearly the nature of shared therapeutic goals in the care giver patient relationship. The conversation envisaged here serves as an important reminder that the patient is the primary deci- 
sion maker in matters of treatment and care. The patient bears the burdens and consequences of these decisions and, for this reason, the patient's interests must always be at the centre of our deliberations.

A thoughtful and sensitive approach to decision making concerning DNR orders helps us to see more clearly the essential reciprocity between care giver and patient. This reciprocity is ultimately about respect for persons. Here, it is important to note that this reciprocity does not mean that one party in the relationship imposes a decision on another, nor does it mean that one party in the relationship must sacrifice deeply held personal or professional values and beliefs, for the sake of reaching a desired outcome.

\section{Ethical difference}

Parties to a DNR decision may experience personal conflict, uncertainty or "moral dis-ease." What might this mean for the anaesthetist? The anaesthetist will first have to be aware of certain threshold or "boundary conditions" that define the therapeutic relationship with patients. Here, the thoughtful anaesthetist will have to distinguish between a situation where one might disagree with a proposed course of action but can accept it, recognising the right of a patient to make a different choice and a situation where one disagrees and cannot cooperate because it would compromise personal or professional integrity. The importance of attending to this experience should not be trivialised or underestimated. In cooperating with actions or decisions that one believes to be wrong, the practitioner risks compromising professional or personal integrity. Repeated compromise, when confronted with serious moral questions, can lead to the experience of "moral residue."

\section{Summary}

The status of DNR orders (or equivalent declarations) in patients undergoing surgery will continue to present considerable challenges for both healthcare providers and patients, or their alternate decision makers. It is essential that all parties understand the specifics of each DNR order, focusing not only on the actual content of the order or declaration but also on the context in terms of location, timing and circumstance. The principle of "respect for persons" should guide, inform and shape the approach followed with each patient. Meaningful dialogue and "negotiation" will be required.

Make no assumptions! The "required reconsidera-

\footnotetext{
a Webster, GC. "Moral Residue": The Problem of Moral Compromise. Panel Presentation, Canadian Biocthics Society Annual Meeting, Vancouver, BC, 1995.
}

tion" of pre-existing DNR orders should be the basic approach followed. There is no single "solution" for all DNR-related issues in the peri-operative period. What may appear obvious to the anaesthetist may be viewed entirely differently by the patient, or even by other members of the care giving team. There is no justification for either the automatic suspension or the automatic continuation of DNR orders in patients undergoing surgery. A patient-specific and situationspecific approach and "solution" is required. Similar principles will apply in acute care settings other than the operating room. Full engagement by health care workers in the processes addressing these issues should be a personally enriching experience.

\section{Acknowledgement}

We thank Pat Murphy, Clinical Ethicist, St. Boniface General Hospital, for helpful comments and suggestions during the preparation of this paper.

\section{References}

1 Optimal care for hopelessly ill patients. A report of the Clinical Care Committee of the Massachusetts General Hospital. N Engl J Med 1976; 295: 362-4.

2 Rabkin MT, Gillerman G, Rice NR. Orders not to resuscitate. N Engl J Med 1976; 295: 364-6.

$3 \mathrm{Keffer} M J$, Keffer $H L$. Do-not-resuscitate in the operating room: moral obligations of anesthesiologists. Anesth Analg 1992; 74: 901-5.

4 Walker RM. DNR in the OR. Resuscitation as an operative risk. JAMA 1991; 266: 2407-12.

5 Younger SJ, Cascorbi HF, Shuck JM. DNR in the Operating Room. Not really a paradox. JAMA 1991; 266: 2433-4.

6 Cohen CB, Cohen PJ. Do-not-resuscitate orders in the operating room. N Engl J Med 1991; 325: 1879-82.

7 Martin RL, Soifer BE, Stevens WC. Ethical issues in anesthesia: management of the do-not-resuscitate patient. Anesth Analg 1991; 73: 221-5.

8 Truog RD. "Do-not-resuscitate" orders during anesthesia and surgery. Anesthesiology 1991; 74: 606-8.

9 Schecter WP. Withdrawing and withholding life support in geriatric surgical patients. Ethical considerations. Surg Clin North Am 1994; 74: 245-59.

10 Layon AJ, Dirk L. Resuscitation and DNR: ethical aspects for anaesthetists. Can J Anaesth 1995; 42: 134-40.

11 Craig $D B$. Do not resuscitate orders in the operating room. Can J Anaesth 1996; 43: 840-51.

12 Margolis JO, McGrath BJ, Kussin PS, Schwinn DA. Do not resuscitate (DNR) orders during surgery: ethical foundations for institutional policies in the United States. Anesth Analg 1995; 80: 806-9.

13 Waisel $D B, \operatorname{Trugg} R D$. The end-of-life sequence. 
Anesthesiology 1997; 87: 676-86.

14 McKnight DJ, Webster GC. Refusal of treatment and

1995) Can Med Assoc J 1995; 153: 1652A-C.

[http://www.cma.ca/canmed/policy/joint95e.htm]

16 Casarett $D$, Ross $L F$. Overriding a patient's refusal of treatment after an iatrogenic complication. $\mathrm{N}$ Engl J Med 1997; 336: 1908-10.

17 Ethical guidelines for the anesthesia care of patients with do-not-resuscitate orders or other directives that limit treatment. (1993) American Society of Anesthesiologists, Park Ridge, Illinois. (ASA Directory of Members 1997: 400-1). [http://www.asahq.org/Standards/SG_09.html]

18 Statement on advance directives by patients: "do not resuscitate" in the operating room. American College of Surgeons, Chicago, Illinois. Bulletin of the American College of Surgeons, September 1994.

[http://www.facs.org/fellows_info/statements/st-19.html]

19 Cohen CB, Coben PJ. Required reconsideration of "do-not-resuscitate" orders in the operating room and certain other treatment settings. Law Med Health Care $1992 ; 20: 354-63$.

20 Policy Regarding Appropriate Use of Cardiopulmonary Resuscitation (CPR). Administrative Policy VI- 290, November 5, 1996. St. Boniface General Hospital, Winnipeg, Manitoba.

21 Dickens $B$. The modern law on informed consent. Modern medicine in Canada. 1982; 37: 706-10. 


\section{Les prescriptions «Ne pas réanimer» - gérer un dilemme}

$\mathrm{L}$ A présence d'une prescription «Ne pas réanimer» (NPR) pour un patient devant subir une opération crée un dilemme pour l'anesthésiste et les autres personnes responsables des soins du patient. Est-ce que la prescription NPR devrait être suspendue en tout ou en partie? Devrait-elle être maintenue sous une forme écrite ou dans une version modifiée? Est-ce que le maintien ou le suspens de la prescription NPR met l'anesthésiste dans une situation de conflit moral? Cette revue examine les bases des différents éléments de ce dilemme et sa solution. Bien que notre revue soit spécifiquement axée sur les prescriptions NPR en salle d'opération, des incertitudes similaires apparaissent aussi lorsqu'on veut respecter le statut NPR dans les autres endroits de soins aigus, par exemple dans les unités de soins intensifs (SI).

Dans notre opinion, le «respect de la personne" est le principe sous-jacent qui devrait guider, informer et modeler le processus décisionnel. Nous en discuterons plus loin lorsque nous définirons notre approche des prescriptions NPR.

$\mathrm{La}$ question générale des prescriptions NPR a évolué depuis le début des années 1970 alors qu'on a commencé à mettre en doute les résultats de l'application diffuse et sans discernement des moyens de réanimation. ${ }^{1,2}$ La question spécifique des prescriptions NPR pour les patients subissant une opération est l'objet d'analyses plus récentes. ${ }^{3-13}$ Quelques-uns des premiers articles ont mis en doute la compatibilité d'une opération chirurgicale et d'une prescription NPR, suggérant que les prescriptions NPR soient automatiquement suspendues durant l'opération ou, plus spécifiquement durant toute la période périopératoire. Des analyses plus récentes ont confirmé la nécessité de certaines interventions chirurgicales chez des patients avec prescriptions NPR. Dans ces circonstances, il a été important de trouver des manières correctes d'ajuster des prescriptions NPR préexistantes. En même temps, on souligne qu'il n'est pas correct d'accepter simplement les prescriptions NPR telles qu'elles sont rédigées et sans discussion ce qui amène à suggérer que les prescriptions NPR devraient être révisées et modifiées, le cas échéant, lorsque les patients subissent une opération.
Douglas B. Craig MD FRCPC, *

George C. Webster DMIN ${ }^{\dagger}$
Un élément supplémentaire dans la discussion a été la reconnaissance des soucis éthiques personnels et professionnels de l'anesthésiste et du personnel soignant amenés à s'occuper d'un patient avec une prescription NPR ou d'autres restrictions au traitement. ${ }^{3,10,14}$ Nous conclurons notre revue par un commentaire sur ce sujet.

En raison de l'importance et de la complexité de beaucoup d'éléments interdépendants du problème NPR, nous avons trouvé utile de revoir directement quelques-uns des éléments de base du problème, plutôt que de renvoyer le lecteur à des analyses antérieures. Après avoir revu ces analyses, nous suggérerons des approches qui devraient aider le personnel soignant à travailler dans ces situations où le patient avec une prescription NPR doit subir une anesthésie et une opération.

Pour conclure notre introduction, nous précisons que bien que les aspects légaux spécifiques de la question NPR varient entre les pays, ou même à l'intérieur d'un pays, les principes généraux de cette analyse, basée sur la situation au Canada, peuvent probablement aussi s'appliquer ailleurs.

\section{L'origine des prescriptions NPR}

Les prescriptions "ne pas réanimer» un patient ont habituellement deux origines. Une prescription NPR peut soit être proposée par un membre du personnel soignant, soit provenir du patient ou de sa famille. Dans le premier cas, un "traitement" particulier, surtout la réanimation cardio-pulmonaire ( $R C P$ ) peut ne pas être «indiqué médicalement» pour un patient donné. Ceci concernerait par exemple un patient connu pour présenter un cancer diffusément métastatique qui n'a pas répondu au traitement et qui va probablement décéder de sa maladie dans un avenir proche.

La nécessité d'une prescription confirmant que la réanimation n'est pas indiquée est apparue lorsque l'application de la RCP dans les cas d'arrêt cardiaque ou respiratoire a été presqu'universelle, dès le début des années 1960. L'incertitude entourant cette question a abouti au Canada, après un processus long et complexe, à la publication d'une Déclaration Commune sur les Interventions en Réanimation (Joint Statement on Resuscitative Interventions $)^{15}$. Cette Déclaration a été préparée par 
l'Association Canadienne des Professions de Santé (Canadian Healthcare Association), l'Association Médicale Canadienne, l'Association Canadienne des Infirmières et l'Association Canadienne Catholique de la Santé. La Déclaration décrit une analyse succincte du problème de la réanimation de base et tente de définir quand les mesures de réanimation sont appropriées et quand elles ne le sont pas. Alors que la Déclaration remarque qu' «il n'y a pas d'obligation à offrir à une personne un traitement en vain ou sans bénéfice», elle reconnaît également la complexité de ces concepts et laisse à chaque institution individuelle de soins la tâche de définir les actes faits «en vain» ou «sans bénéfice». Néanmoins, la Déclaration apporte un fondement solide pour la discussion des prescriptions NPR, dans les conditions décrites dans la Déclaration Commune. Elle met aussi clairement en évidence que la présence de prescriptions NPR ne signifie pas l'interruption ou le retrait d'autres formes de traitement, incluant la chirurgie, les soins palliatifs ou autres traitements. Les éléments clés de la Déclaration se référant aux principes directeurs des politiques de RCP, aux indications à la réanimation et aux prescriptions NPR en l'absence de telles indications sont résumés dans les tableaux I, II et III.

Une prescription NPR, ou son équivalent, peut faire suite à un déclaration du patient, ou de quelqu'un autorisé à agir au nom du patient, dans le but de limiter les interventions futures. Une décision de la part d'un patient acceptant une suite d'examens ou de traitements doit être une «décision éclairée». Le consentement éclairé est une exigence légale et éthique fondamentale dans la relation soignant-patient. Il est maintenant largement admis que tout patient qui a la faculté de décider peut accepter ou refuser un examen ou un traitement recommandé, même si le refus peut, aux yeux du soignant, entraîner des conséquences non désirées voire un décès. Pour certains, le «droit de refuser» est absolu et, contrairement à la théorie du consentement éclairé, le refus n'est limité par aucune contrainte légale concernant l'accès à l'information de ceux qui refusent le traitement. Malgré cela, la prémisse fondamentale des soins à une personne dicte que même en l'absence d'obligation légale, il y a une obligation morale pour le soignant de faire en sorte que la décision de refuser un traitement soit éclairée.

En plus d'une déclaration directe par une personne compétente refusant toute tentative funure de réanimation, des directives antérieures (des instructions et/ou des directives par procuration), exécutées correctement sont un autre moyen pour un individu d'exprimer une décision de renoncer à la RCP.

La reconnaissance qu'une prescription NPR (ou son équivalent) provenant d'un patient ou d'un déci-
TABLEAU I Principes de conduite pour les politiques de RCP

- Communication/discussion/sensibilité libres

- Information suffisante sur les bénéfices/risques/conséquences probables

- Droit du patient à refuser ou à retirer son consentement

- Droits égaux pour les patients incapables de prendre leurs propres décisions

- Aucune obligation à offrir un traitement vain ou sans bénéfice

\section{TABLEAU II Résultats de la RCP}

\section{Bénéfice probable}

- Il y a une probabilité élevée que la RCP restaure les fonctions cardiaque et respiratoire et que celles-ci, une fois restaurécs soient maintenues. La probabilité qu'unc personne retrouve sa condition d'avant l'arrêt est élevée.

\section{Bénéfice incertain}

- La condition de la personne ou son pronostic ou les deux peuvent ne pas avoir été évalués avant la perte des fonctions cardiaques et respiratoires. La restauration de ces fonctions est inconnue ou incertaine. Par conséquence, le pronostic ou la probabilité de suites indésirables sont aussi inconnus ou incertains

\section{Bénéfice improbable}

- Il y a peu de chance que la RCP ne restaure les fonctions cardiaque et respiratoire; même si la fonction est restaurée, il est improbable qu'elle se maintienne. La probabilité que le patient retrouve sa condition d'avant l'arrêt est faible

\section{Bénéfice absent}

- De façon presque certaine, il n'y a aucune chance pour que la personne bénéficie de la RCP, soit parce que la maladie ou l'affection sous-jacente rend la récupération de l'arrêt un événement quasi sans précédent soit parce que la personne va être incapable de façon permanente d'en tirer quelque bénéfice que ce soit.

TABLEAU III Situations où la RCP devrait/ne devrait pas être entreprise

\section{Devrait}

- Les personnes susceptibles de béneficier de la RCP devraient recevoir ce traitement en cas de besoin, sauf si elles l'ont spécifiquement refusé.

- Les personnes pour qui le bénéfice de la RCP est incertain ou improbable devraient recevoir ce traitement en cas de besoin, sauf si elles l'ont spécifiquement refusé. La RCP devrait être déburée jusqu'à ce que la condition de la personne ait été évaluée.

Ne devrait pas

- Les personnes qui ont refusé la RCP et ceux qui de manière presque certaine n'en bénéficieront pas ne devraient pas recevoir ce traitement en cas d'arrêt.

sionnaire substitut peut avoir été émise sans une information complète et correcte, particulièrement concernant les particularités de l'anesthésie et des soins péri-opératoires, est de première importance. Il est également important de reconnaître qu'une prescription NPR peut avoir été écrite ou communiquée à un décisionnaire substitut à une époque éloignée alors 
que les circonstances précises actuelles pourraient ne pas avoir été anticipées lors de son élaboration.

\section{Événements iatrogènes}

Le sujet concernant les événements iatrogènes (définis au sens large par la survenue d'événements indésirables suite à des interventions diagnostiques ou thérapeutiques) a été identifié comme un des éléments les plus troublants dans la discussion NPR en salle d'opération. Ce sujet, déjà décrit dans quelques analyses antérieures, a seulement récemment été spécifiquement examiné en détail. ${ }^{16}$ Casarett et Ross discutent la complication iatrogène comme possible raison valable de modifier un ordre NPR, mais rejettent l'hypothèse que l'origine de la complication justifie d'outrepasser cette prescription. Leur rejet vient d'une analyse de l'équilibre entre le principe de non maléficience (ne pas faire de mal) et celui de respect de l'autonomie du patient. Ils suggèrent que, compris comme un équilibre, le principe de non maléficience n'établit qu'un devoir partiel ou apparent d'éviter de faire du mal et que ceci ne devrait pas dépasser le respect de l'autonomie du patient tel qu'exprimé dans la directive antérieure. Ils rejettent aussi la notion que la réanimation après un arrêt cardiaque iatrogène, malgré une prescription NPR valable, est automatiquement justifiée parce qu'il est probable qu'elle soit réussie.

En même temps, ils remarquent qu'il y aura des circonstances où une directive antérieure (quelque soir sa forme) devra être outrepassée. La raison en est dans l'intention de la déclaration antérieure, remarquant que souvent il s'agit d'une déclaration générale, et qu'il peut y avoir plusieurs significations. Idéalement ces distinctions importantes devraient avoir été résolues par avance soit lors de la rédaction de la prescription NPR, soit après celle-ci en relation alors avec les circonstances spécifiques dans lesquelles se trouve le patient. La possibilité de complications iatrogènes, et leur nature, peut et devrait être discutées avec le patient compétent ou avec un décisionnaire substitut approprié. Il est important de noter, en relation avec le problème des prescriptions NPR en salle d'opération, que Casarett et Ross n'incluent pas dans leur analyse les situations spécifiques en rapport avec l'anesthésie ou d'autres soins péri-opératoires.

Gestion des prescriptions NPR en salle d'opération Depuis la publication des premiers articles concernant les prescriptions NPR en salle d'opération, il y a eu une évolution dans l'approche proposée de la gestion des prescriptions NPR pour les patients subissant une opération. Les premières propositions concernant ce sujet tendaient à ne s'intéresser qu'à deux options: la continuation automatique ou la suspension automatique des prescriptions NPR durant toute la période péri-opératoire. Celles-ci ont été remplacées par des considérations plus complexes qui sont décrites ci-dessous.

Quelques partisans de la suspension automatique suggèrent qu'il y a une incompatibilité absolue entre une prescription NPR et une opération chirurgicale. La suspension automatique est associée aussi à une opportunité évidente et attirante (pour certains) de pratiquer l'opération prévue sans devoir comprendre ou même penser au problème de base.

Il est important de remarquer dans ce contexte que l'application automatique (c'est-à-dire sans discussion avec le patient ou son mandataire) des prescriptions NPR pour les patients subissant une opération pose aussi des problèmes.

Un thème important de la littérature croissante concernant les prescriptions NPR en salle d'opération a été l'avertissement que ceux qui donnent des soins à un patient comprennent, aussi clairement et complètement que possible, le contexte d'une prescription NPR. Quand et pourquoi la prescription a été émise? Les circonstances ont-elles changé? La décision d'émettre une prescription NPR a-t-elle été une décision éclairée? La prescription est-elle claire et spécifique ou sujet à interprétation? Un autre sujet très important est la distinction entre la signification de «réanimation» telle que comprise par des patients et beaucoup de professionnels de la santé et celle du même terme par les anesthésistes praticiens. Le fait que l'administration de liquides intraveineux, de relaxants musculaires et de médicaments vasoactifs, l'intubation trachéale et la ventilation mécanique et les autres procédures «invasives» soient une partie routinière de l'anesthésie moderne n'est probablement pleinement compris que par les anesthésistes praticiens eux-mêmes. Il est donc primordial que les détails de ces activités si routinières soient discutées non seulement avec le patient, mais aussi avec les autres personnes impliquées dans les soins du patient. Dans ce cas, la qualité de la communication et non seulement la quantité d'informations partagées entre l'anesthésiste et le patient est de toute importance. Cette "communication" est le coeur de toute relation thérapeutique. Si l'intention du patient est de refuser son consentement par l'entremise d'une prescription NPR seulement pour le cas d'arrêt cardiopulmonaire, tout en acceptant dans le même temps d'autres éléments de la "réanimation", celle-ci doit être discutée à l'avance, dans la mesure du possible.

\section{Réépaluation obligatoire}

En 1993, l'American Society of Anesthesiologists (ASA) a été la première organisation à publier des lignes directrices (Guidelines) concernant les prescriptions NPR ou 
d'autres équivalents limitant le traitement. ${ }^{17}$ Un an plus tard, l'American College of Surgeons (ACS) a publié un rapport concernant le même sujet. ${ }^{i 8}$ Les lignes directrices de l'ASA et le rapport de l'ACS rejettent toutes les deux l'idée de suspension automatique. Les lignes directrices de l'ASA font remarquer que la politique de suspension automatique "peut ne pas tenir compte suffisamment des droits du patient à l'autodétermination de manière responsable et éthique». Le rapport de l'ACS est d'accord mais ajoute aussi qu'une politique qui automatiquement maintient et applique toutes les prescriptions NPR est également inadéquate et peut amener à une conduite anesthésique et periopératoire inappropriées. Le rapport conclut par une recommandation pour qu'il y ait une politique de «réévaluation obligatoire" des directives antérieures avant une opération, approche proposée initialement par Cohen et Cohen en $1992 .{ }^{19}$

Au moment de la préparation de ce résumé (décembre 1997) les auteurs n'étaient au courant d'aucune ligne directrice nationale au Canada (publiée ou en préparation) similaire à celles publiées par l'ASA et l'ACS. C'est une grave lacune qu'il faut combler. Malgré l'absence de lignes directrices nationales, certains hôpitaux ont inclus dans leur politique d'utilisation correcte de la RCP des clauses réclamant la révision des prescriptions NPR dans des circonstances spécifiques, par exemple en rapport avec les soins chirurgicaux ou le transfert en milieu de SI.

L'approche de «réévaluation obligatoire» proposée par Cohen et Cohen ${ }^{19}$ était pour une réévaluation obligatoire des prescriptions NPR basée soit sur la durée pendant laquelle la prescription avait déjà été appliquée soit sur le type de traitement. Ils suggèrent que le transfert d'un patient d'un endroit (par exemple un foyer pour personnes âgées) où la survie après un arrêt cardiaque est improbable, dans un autre environnement (par exemple un hôpital de soins aigus) où des traitements spécifiques et limités dans le temps augmentent le risque d'arrêt cardiaque, mais où la réanimation disponible immédiatement rend le résultat favorable plus probable, mérite la réévaluation des caractéristiques d'une prescription NPR.

\section{Une proposition modeste}

À l'exception de situations cliniques où un délai n'est pas possible, nous pensons que le statut des prescriptions NPR doit être révisé selon l'approche de réévaluation obligatoire discutée ci-dessus. Une première phase dans le processus de réévaluation concerne les détails de la prescription NPR elle-même, sans rapport avec l'opération chirurgicale proposée. Tout le contexte d'une prescription NPR doit être compris à la fois par le patient et par le personnel soignant. Il ne doit pas y avoir de supposition. Les raisons d'être de la prescription NPR sontelles toujours valables? La prescription NPR est-elle claire, sans ambiguité à la fois pour le patient (ou pour le mandataire de celui-ci), pour le médecin et pour les autres professionnels de la santé qui s'occupent du patient? Des changements à la prescription NPR sont-ils justifiés sans tenir compte de l'opération à venir?

On pense souvent dans une discussion au sujet d'une prescription NPR que chaque partie comprend le but et l'importance de celle-ci. Quelques prescriptions NPR, particulièrement celles transmises par une directive écrite par anticipation, peuvent être très difficiles à interpréter. Il n'est souvent pas facile de savoir ce que l'individu a compris lors de la rédaction de la directive par anticipation et les professionnels de la santé ont souvent beaucoup de peine à «traduire» l'instruction écrite dans la situation ou le contexte actuel. Les professionnels de la santé ou occasionnellement des mandataires peuvent avoir des doutes importants pour savoir si des patients qui en sont actuellement incapables avaient réellement compris ce qu'ils avaient «accepté» lorsqu'ils ont rempli leur directive par anticipation.

Notre première proposition est donc la création d'un point de départ aussi clair et compréhensible que possible (pour toutes les parties), permettant ainsi aux étapes suivantes concentrées sur le problème de la prescription NPR durant l'opération d'être réglées selon le besoin. Nous remarquons un point commun aux deux prises de position de l'ASA et de l'ACS, ainsi qu'un message important de beaucoup d'articles récents, qui reconnaissent tous qu'il n'existe pas de «solution» unique et correcte pour chaque situation. Alors qu'on traite différents patients pour une situation clinique qui semble être similaire, il peut être approprié et acceptable de maintenir la prescription NPR inchangée pour la période périopératoire, de la conserver mais d'en modifier la forme ou de la suspendre. Des options similaires vont probablement aussi se présenter pour un même patient mais dans des situations cliniques différentes. L'approche au problème de la prescription NPR doit ainsi être individualisée et ajustée de manière à correspondre aux besoins individuels et autant que possible respecter les valeurs de chaque patient:

Un dialogue franc et ouvert avec le patient (ou un mandataire) est essentielle. Cette conversation se doit d'inclure non seulement toute l'information et la réponse aux questions, mais encore devrait être caractérisée par ce que certains auteurs ont appelé un processus de "négociations». Waisel et Truog suggèrent que ce processus ait pour but un «accord universel et négocié» entre le patient comme une partie et les membres de l'équipe soignante comme autre partie. ${ }^{13}$ 
Les lignes directrices de l'ASA proposent que cette discussion/négociation soit une approche principalement basée sur les moyens, détaillant les éléments de soins spécifiques (par exemple: massage cardiaque, support ventilatoire postopératoire, utilisation de médicaments vasoactifs) qui devraient être discutés en relation avec chaque situation de soins. Il faut reconnaitre cependant que cette approche ne sera pas appropriée ou même possible pour tous les patients et dans toutes les situations.

Une deuxième approche est basée plutôt sur le but que sur les moyens et est centrée sur la mise en évidence et la clarification des idées et des préférences du patient en ce qui concerne son devenir. Dickens a remarqué l'importance de différencier les «méthodes» de traitement des «buts" de celui-ci. ${ }^{21}$ Dans ce contexte de consentement et de relation thérapeutique, Dickens a observé que les médecins et d'autres membres du personnel soignant donnent des informations au patient concernant son diagnostic, son pronostic et les moyens disponibles pour traiter une condition ou une maladie particulière. Les patients, de leur côté, amènent une certaine "histoire" dans la relation thérapeutique qui est inspirée et façonnée par leurs valeurs et croyances personnelles. Les médecins et les autres membres du personnel soignant doivent discuter avec les patients avec l'intention d'en apprendre davantage sur les croyances et le système de valeurs de ceux-ci. De cette manière, ils vont pouvoir connaître plus clairement la nature des buts thérapeutiques partagés dans la relation soignant-patient. La conversation que l'on envisage ici sert surtout à rappeler que le patient est le principal décisionnaire en ce qui concerne le traitement et les soins. Le patient porte la charge et assume les conséquences de ces décisions et, c'est pour cette raison, que les intérêts du patient doivent être au centre de nos réflexions. Une approche réfléchie et sensible à la décision concernant les prescriptions NPR nous aide à distinguer plus clairement la réciprocité indispensable à la relation soignant-patient. Cette réciprocité est finalement le respect de la personne. Ici, il est important de noter que cette réciprocité ne signifie pas qu'une des parties dans la relation impose une décision à l'autre partie, ni qu'une des parties doit renoncer à ses valeurs et croyances personnelles intimes dans le but d'arriver au résultat recherché.

\section{Différence éthique}

Les parties prenant part à une décision concernant les prescriptions NPR peuvent vivre un conflit personnel, de l'incertitude ou un «trouble moral». Qu'est ce que cela signifie pour l'anesthésiste? L'anesthésiste devra d'abord être conscient de certaines limites ou de «conditions limitantes" qui définissent la relation thérapeutique avec les patients. Ainsi, l'anesthésiste attentif devra distinguer entre une situation où l'on peut désapprouver une attitude proposée tout en l'acceptant reconnaissant par là le droit du patient de faire un choix différent et une situation que l'on désapprouve et où on ne peut coopérer car cela compromettrait son intégrité personnelle ou professionnelle. L'importance de vivre cette expérience ne doit pas être banalisée ou sous-estimée. S'il coopère à des actes ou des décisions qu'il pense être fausses, le praticien risque de compromettre son intégrité professionnelle ou personnelle. Des compromis répétés lorsqu'on est confronté à de graves questions morales peuvent aboutir à la sensation de "résidu moral». (Webster, GC. «Moral Residue»: The Problem of Moral Compromise. Panel Presentation, Canadian Bioethics Society Annual Meeting, Vancouver, BC, 1995).

\section{Résumé}

Le problème des prescriptions NPR (ou leur équivalent) pour les patients qui vont être opérés va continuer de présenter des défis importants à la fois aux personnel soignant et aux patients, ou à ceux qui prennent les décisions en leur nom. Il est essentiel que toutes les parties comprennent les particularités de chaque prescription NPR, en se concentrant non seulement sur le contenu présent de la prescription ou de la déclaration mais aussi sur le contexte en termes de localisation, temps et circonstances. Le principe du «respect de la personne» devrait guider, informer et ajuster l'approche que l'on adopte pour chaque patient. Un dialogue sérieux et une «négociation» seront nécessaires. ${ }^{2}$

$\mathrm{Ne}$ faites pas d'hypothèses! La «réévaluation obligatoire» d'une prescription NPR préexistante devrait être l'approche principale à suivre. Il n'y a pas de «solution» unique pour tous les problèmes en rapport avec les prescriptions NPR durant la période périopératoire. Ce qui peut apparaître évident à un anesthésiste peut être perçu complètement différemment par le patient, ou même par d'autres membres de l'équipe soignante. Il n'y a aucune justification pour la suspension automatique ou la poursuite automatique des prescriptions NPR des patients devant être opérés. Une approche et une «solution» spécifique à chaque patient et à chaque situation sont

\footnotetext{
a Webster, GC. "Moral Residue": The Problem of Moral Compromise. Panel Presentation, Canadian Bioethics Society Annual Meeting, Vancouver, BC, 1995.
} 
nécessaires. Des principes similaires s'appliquent dans des unités de soins aigus autres que la salle d'opération. Un engagement total du personnel soignant dans la résolution de ces problèmes devrait être une expérience personnelle enrichissante.

\section{Remerciements}

Nous remercions Pat Murphy, spécialiste en éthique

tion de ce document.

\section{Références}

(Voir page Rl64) 